ISSN 0206-5657. Вісник Львівського університету. Серія біологічна. 2019. Випуск 81. С. 21-28 Visnyk of the Lviv University. Series Biology. 2019. Issue 81. P. 21-28

\title{
БOTAHIKA
}

УДК $581.1+582.54$

https://doi.org/10.30970/vbi.2019.81.03

\section{SEED PROTEINS ANALYSIS OF FESTUCA SERIES PSAMMOPHILAE M. PAWLUS AND OVINAE M. PAWLUS (POACEAE)}

\author{
I. Bednarska ${ }^{1}$, G. Angelov ${ }^{2}$ \\ ${ }^{1}$ Institute of Ecology of the Carpathians, NAS of Ukraine \\ 4, Kozelnytska St., Lviv 79026, Ukraine \\ e-mail: ibednarska@ukr.net \\ ${ }^{2}$ Institute of Biodiversity and Ecosystem Research Bulgarian Academy of Sciences \\ Acad. G. Bonchev St., Bl. 23, Sofia 1113, Bulgaria \\ e-mail:jorkata_1953@mail.bg
}

According to the type of leaf anatomy, narrow-leaved fescues could be divided to three main groups: species with leaves as in Festuca rubra (sclerenchyma strands small, numerous), type $F$. valesiaca ( 3 main and big sclerenchyma strands + adventive) and type $F$. ovina (sclerenchyma ring). The species of the last group were chosen in our study. The seed proteins variation in natural populations of Festuca vaginata, F. psammophila, F. pallens, $F$. polesica and $F$. ovina from Ukraine and Bulgaria was examined by means of polyacrylamide (PAGE) and sodium dodecyl sulphate (SDS-PAGE) electrophoresis. These fescues exhibit high variability and overlap of morphological and anatomical characters, including diagnostic ones, leading to identification difficulties and uncertainties in their taxonomy. The purpose of the present study was to analyze seed protein composition in order to reveal systematic relationships among the above mentioned taxa of genus Festuca. The results showed that $F$. vaginata, F. psammophila and $F$. polesica are closely related. The species $F$. pallens was relatively distant from the above mentioned three species. The specific position of $F$. pallens is confirmed also by its ecological characteristics- it is the only species growing on carbonate rocks, while the rest of taxa are typical psammophytes. The results showed distinct differences between Ukrainian populations of $F$. pallens and $F$. psammophila and confirmed occurrence of latter in Ukrainian Roztocha. The cluster patterns were somewhat inconsistent in regard to different types of proteins (PAGE, SDS-PAGE). The only exception is $F$. ovina, which always occupies a separate position. This confirms its remote position within the studied group of the genus Festuca and supports the view to consider F. ovina s.str. as a separate series Ovinae among the species with sclerenchyma ring. Whereas all other studied species ( $F$. vaginata, F. psammophila, F. pallens, F. polesica) should be considered as a separate series of closely related taxa-series Psammophilae.

Keywords: electrophoresis, Festuca, seed proteins, systematic relationships

\section{Introduction}

According to the type of leaf anatomy, narrow-leaved fescues could be divided into three main groups: species with leaves as in Festuca rubra (sclerenchyma strands small, numerous), $F$. valesiaca type ( 3 main and big sclerenchyma strands + adventive) and $F$. ovina type (sclerenchyma ring). The species of the last group were chosen in our study. There are different taxonomic treatments of this group. Two main treatments exist in Eastern Europe. According to the first one $[3,12]$, among the species with sclerenchyma ring there are several small species aggregates, namely $F$. ovina agg. (leaves predominantly green, thin $0,3-0,7 \mathrm{~mm}, 5-7$ veins, $1-3$ ribs: $F$. ovina L., F filiformis Pourr., F. airoides Lam.), F. glauca agg. (or F. pallens s.1.) (leaves bluish, rigid

(C) Беднарська I., Ангелов Г., 2019 
0,6-1,2 mm in diameter, flat, 7-13 veins, 3(-5) triangle ribs: F. pallens Host, F. psammophila (Hack. ex Čelak.) Fritsch) and $F$. beckeri agg. (leaves green, rigid, often trachyphylous, 0,4-0,8 mm, veins 7-11, ribs 5-7, partly flat: F. beckeri (Hack.) Trautv., F. polesica Zapał.). Maria Pawlus [9] proposed an alternative classification, dividing the species with sclerenchyma ring into two series: Ovinae M.Pawlus (F. ovina, F filiformis, F. airoides, F. guestfalica Boenn. ex Rchb.) with thin leaves, 5-7 veins and 1-3 ribs, and series Psammophilae M.Pawlus (F. psammophila, F. polesica, F. vaginata Waldst. \& Kit. ex Willd., F. pallens), which unites the rest of species with more rigid leaves, numerous veins and long trichomes on ribs. Despite of substantial differences among the typical representatives of all mentioned series/aggregates, quite frequently there can be observed specimens (sometimes whole populations) of intermediate type. The phylogenetic relationships among these species groups and their adequate taxonomic treatment still remain unresolved.

The present study includes five taxa of Festuca from Ukraine and Bulgaria: F. vaginata, F. psammophila, F. pallens, F. polesica and F. ovina, which represent all above-mentioned species aggregates.

The five above-mentioned fescues exhibit high variability and overlap of morphological and anatomical characters, including diagnostic ones leading to identification difficulties and uncertainties in their taxonomy. Thus, there is a need to apply different new approaches, including biochemical ones, to reveal the systematic structure and relationships among them. Electrophoretic techniques that separate seed storage proteins are rapid and generally free from environmental effects compared with the traditional morphological and other classical criteria. They indirectly reflect the genome. For these reasons, they are widely employed for estimation of systematic relationships and genetic variation of natural populations and cultivars of different plant taxa $[2$, $4,7,8,10,13]$.

The purpose of the present study was to analyze seed protein composition in order to reveal systematic relationships among the above mentioned taxa of the genus Festuca.

\section{Materials and Methods}

Bulk seeds' samples from natural populations of the above mentioned taxa were collected in Ukraine and Bulgaria (Table 1). Each population sample consisted of 20-30 plants which were identified first by their anatomical and morphological traits. Total seed proteins were extracted by $0.01 \mathrm{M}$ tris, $0.08 \mathrm{M}$ glycine, $20 \%$ sucrose, $\mathrm{pH} 8.3$ and ratio seeds : buffer $=1: 6$. Anodal seed proteins were electrophoretically resolved in vertical polyacryamide slab gels (7.5\% separating, $3 \%$ stacking gels) using slightly modified system of Davis [5]. The length of the separating gel was $8 \mathrm{~cm}$, while the spacer was $1 \mathrm{~cm}$ long. Gels were stained with Coomasie Brilliant Blue R-250 $(0.1 \%)$ in $10 \%$ acetic acid, $45 \%$ methanol for 2 hours and destained in $10 \%$ acetic acid, $10 \%$ methanol for a night.

The discontinuous sodium dodecyl sulphate polyacrylamide gel electrophoresis (SDSPAGE) of proteins was performed as described by Gardiner et al. [7]. The stacking (5\% acrylamide) and separating ( $12 \%$ acrylamide) gels were used. The length of stacking and separating gel was $2 \mathrm{~cm}$ and $12 \mathrm{~cm}$, respectively.

Affinities among the taxa within the studied group were evaluated by the coefficient of similarity $\mathrm{SI}=\mathrm{M} /(\mathrm{M}+\mathrm{N})$, where $\mathrm{M}$ is the number of bands common for compared taxa, $\mathrm{N}$-.the sum of absent bands in each compared taxon. The values of coefficient SI for each pair-wise comparison among the taxa were calculated separately for each set of seed proteins (anodal, SDSPAGE). Then, mean values of coefficient SI as an average on the two data sets were calculated in order to assess overall affinities among the taxa within the studied group of Festuca. An index of group affinity (GA) was calculated for each taxon as a sum of its SI values [6]. 
List of studied taxa and populations of Festuca

\begin{tabular}{|c|c|c|}
\hline № & Taxon & Country Location Latitude Longitude \\
\hline & F. vaginata & Bulgaria, Black sea coast, Pobitite camani, $43^{\circ} 13^{\circ} 60,^{\circ} 27^{\circ} 40^{\circ} 0^{\prime \prime}$ \\
\hline & F. vaginata & Bulgaria, Black sea coast, Arcutino, $42^{\circ} 20^{\circ} 4.74^{\prime \prime} \quad 27^{\circ} 43^{\circ} 34.88^{\prime \prime}$ \\
\hline & F. psammophila & Ukraine, Lviv region, Yavoriv district, Stradch $49^{\circ} 53^{\circ} 45.09^{\prime \prime} \quad 23^{\circ} 45^{\prime} 18.69^{\prime \prime}$ \\
\hline & F. pallens & Ukraine, Ternopil region, city Kremenets, tract Divochi Skeli $50^{\circ} 7^{`} 5.78^{\prime \prime}$ \\
\hline & F. pallens & Ukraine, Ivano-Frankivsk region, Galych district, Podilla $49^{\circ} 16^{`} 36.11^{\prime \prime} \quad 24^{\circ} 44^{\circ} 28.97^{\prime}$ ' \\
\hline & F. polesica & Ukraine, Kyiv region, Vyshgorod district, village Hotyanivka $50^{\circ} 37^{`} 3.91^{\prime \prime} \quad 30^{\circ} 33^{\circ} 8.85^{\prime \prime}$ \\
\hline & F. polesica & Ukraine, Volyn region, Lyubeshovsky district, Lyubotin $51^{\circ} 50^{`} 46.66^{\prime \prime} \quad 25^{\circ} 19^{`} 44.61^{\prime “}$ \\
\hline & F. polesica & Ukraine, Kharkiv region, Bogodukhov $50^{\circ} 8^{`} 44.38^{\prime \prime} \quad 35^{\circ} 32^{`} 16.72^{\prime \prime}$ \\
\hline & F. ovina & Ukraine, Kyiv region, Vyshgorod district, Hotyanivka $50^{\circ} 38^{\prime} 54.82 » 30^{\circ} 33^{\prime} 17.26 »$ \\
\hline
\end{tabular}

\section{Results and Discussion}

Anodal seed proteins. Totally eighteen anodally migrating electrophoretic bands were observed in the studied taxa of genus Festuca (Table 2). Bands 29 and 61 were shared by all taxa. Except $F$. ovina, electrophoretic bands 12,41 and 45 were common for the studied group. Similarly, band 50 was observed in all taxa but absent in F. pallens. Band 23 was detected in F. pallens and $F$. ovina only. Electrophoretic band 53 was species-specific for $F$. pallens.

Table 2

Banding profiles of anodal seed proteins in the studied taxa of Festuca.

1 - band present, 0 - band absent. Each band was designated by a number reflecting its migration (in $\mathrm{mm}$ ) from the origin.

\begin{tabular}{|c|c|c|c|c|c|c|c|c|c|c|c|c|c|c|c|c|c|c|}
\hline \multirow{2}{*}{ Taxon } & \multicolumn{18}{|c|}{ Electrophoretic band } \\
\hline & 12 & 18 & 21 & 23 & 29 & 31 & 38 & 41 & 44 & 45 & 48 & 50 & 51 & 53 & 54 & 55 & 61 & 63 \\
\hline F. vaginata & 1 & 1 & 1 & 0 & 1 & 1 & 0 & 1 & 1 & 1 & 1 & 1 & 1 & 0 & 1 & 1 & 1 & 1 \\
\hline F. psammophila & 1 & 0 & 1 & 0 & 1 & 1 & 1 & 1 & 1 & 1 & 0 & 1 & 0 & 0 & 1 & 1 & 1 & 0 \\
\hline F. pallens & 1 & 1 & 1 & 1 & 1 & 1 & 1 & 1 & 0 & 1 & 0 & 0 & 1 & 1 & 0 & 0 & 1 & 0 \\
\hline F. polesica & 1 & 0 & 0 & 0 & 1 & 0 & 0 & 1 & 0 & 1 & 1 & 1 & 1 & 0 & 1 & 1 & 1 & 1 \\
\hline F. ovina & 0 & 1 & 0 & 1 & 1 & 0 & 1 & 0 & 1 & 0 & 0 & 1 & 0 & 0 & 0 & 0 & 1 & 0 \\
\hline
\end{tabular}

The values of coefficient SI varied in a wide range from 0.20 ( $F$. ovina vs $F$. polesica) to 0.73 when the latter species was compared to $F$. vaginata (Table 3 ). The latter species demonstrated also high affinity to F. psammophila and F. polesica. The species $F$. ovina proved to be most isolated within the studied group as its SI values were the lowest for all pair-wise comparisons.

Table 3

Coefficient of similarity (SI) values for pair-wise comparisons among the studied taxa of genus Festuca - anodal seed proteins

\begin{tabular}{|l|c|c|c|c|c|}
\hline \multirow{2}{*}{ Taxon } & \multicolumn{5}{c|}{ Coefficient of similarity (SI) values } \\
\cline { 2 - 6 } & 1 & 2 & 3 & 4 & 5 \\
\hline 1. F. vaginata & 1.00 & 0.69 & 0.50 & 0.73 & 0.29 \\
2. F. psammophila & 0.69 & 1.00 & 0.43 & 0.50 & 0.38 \\
3. F. pallens & 0.50 & 0.43 & 1.00 & 0.37 & 0.36 \\
4. F. polesica & 0.73 & 0.50 & 0.37 & 1.00 & 0.20 \\
5. F. ovina & 0.29 & 0.38 & 0.36 & 0.20 & 1.00 \\
\hline
\end{tabular}

Index of group similarity contributed further to revealing systematic relationships within the examined group of the genus Festuca. Lower values of index GA mean greater distance for a given taxon, and vice versa, higher values are indication for a closer affinity within the group. Considering the index of group affinity $(\mathrm{GA})$, it could be noticed that $F$. ovina $(\mathrm{GA}=1.23)$ is 
most distantly positioned within the group. The species $F$. polesica $(\mathrm{GA}=1.80)$ and $F$. pallens $(\mathrm{GA}=1.66)$ were almost equidistantly positioned while $F$. vaginata $(\mathrm{GA}=2.22)$ was the most tightly bound within the group (Fig. 1).

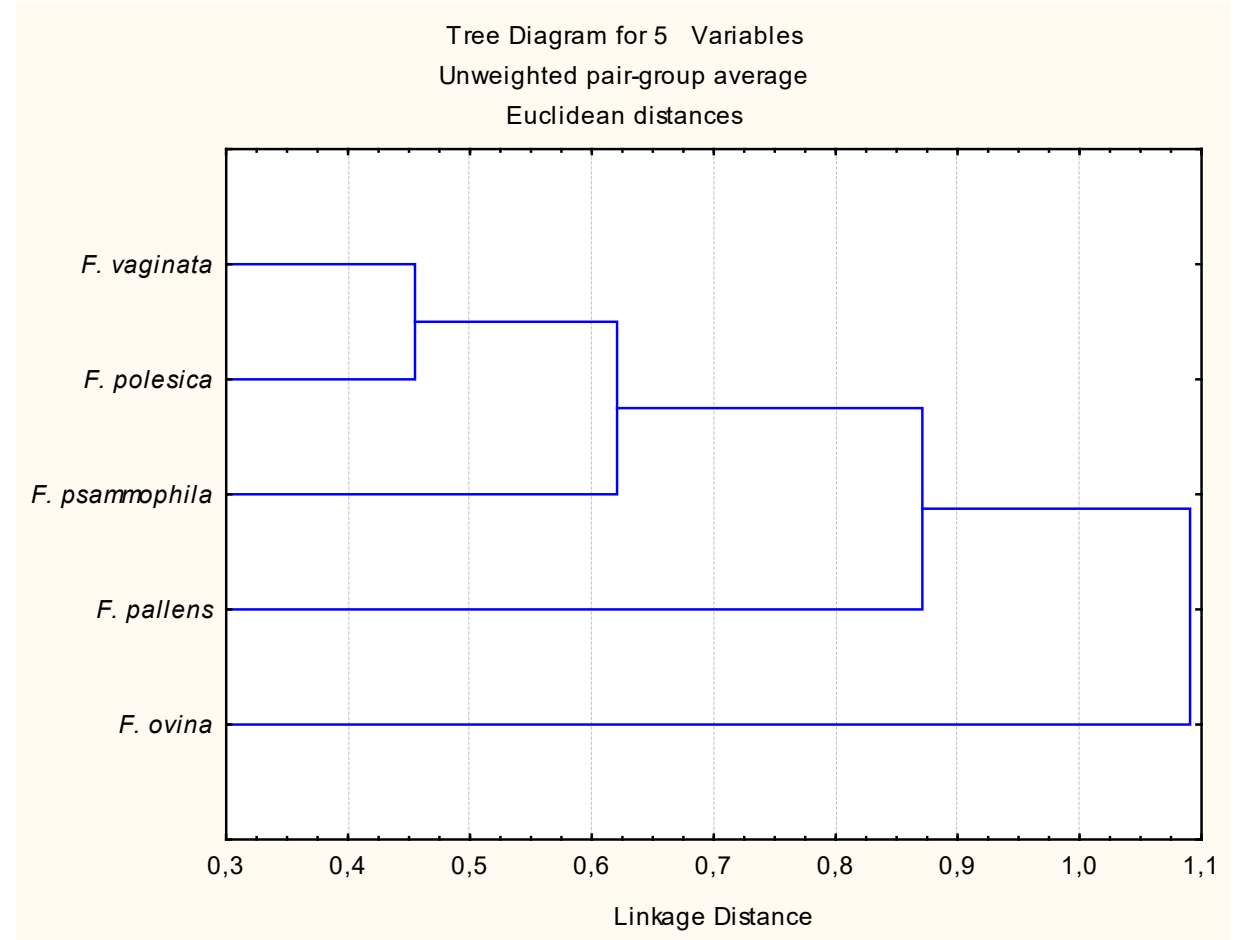

Fig. 1. Cluster analysis dendrogram for the studied Festuca species based on anodal seed proteins

SDS-PAGE seed proteins. Contrary to the PAGE method based on differences of proteins electric charge, the technique of SDS-PAGE separates proteins on the basis of their relative molecular mass. Smaller proteins move faster down the gel than larger ones. Thus, the final band pattern represents the proteins arranged down the gel in decreasing order of their molecular mass. Both enzymatic and storage proteins are extracted. As the storage proteins are major portion of total seed proteins, it is assumed that the patterns are mainly due to the former ones.

Overall, sixteen protein bands were resolved by SDS-PAGE in the seed samples of the studied Festuca species (Table 4). Four electrophoretic bands, namely 32, 43, 68, 100 were observed in all studied species. Except $F$. ovina, bands 52, 62 and 91 were detected throughout the whole group. Electrophoretic band 60 was observed in F. polesica and F. ovina only, whereas the bands 87 and 114 were common for the latter and F. pallens. Electrophoretic band 26 was species-specific for $F$. ovina.

Considering the values of coefficient SI, it was established that $F$. ovina occupied a relatively remote position within the studied group as its SI were the lowest (Table 5). The species $F$. vaginata demonstrated highest affinity to F. polesica and less to F. pallens and F. psammophila.

Analysis of GA values led to the same conclusions. The species $F$. ovina occupied the most remote species within the group as its GA value (1.61) was the lowest one, while the GA values of the other species were ranging from 2.19 to 2.47 - an indication for their high mutual affinity (Fig. 2). 
Banding profiles of SDS-PAGE seed proteins in the studied taxa of Festuca:

1 - band present, 0 - band absent. Each band was designated by a number reflecting its migration (in $\mathrm{mm}$ ) from the origin

\begin{tabular}{|l|c|c|c|c|c|c|c|c|c|c|c|c|c|c|c|c|}
\hline \multirow{2}{*}{ Taxon } & \multicolumn{10}{c|}{ Electrophoretic band } \\
\cline { 2 - 10 } & 26 & 30 & 32 & 43 & 52 & 56 & 60 & 62 & 68 & 77 & 81 & 87 & 91 & 100 & 105 & 114 \\
\hline F. vaginata & 0 & 0 & 1 & 1 & 1 & 1 & 0 & 1 & 1 & 0 & 1 & 0 & 1 & 1 & 1 & 0 \\
F. psammophila & 0 & 0 & 1 & 1 & 1 & 0 & 0 & 1 & 1 & 1 & 0 & 0 & 1 & 1 & 0 & 0 \\
F. pallens & 0 & 1 & 1 & 1 & 1 & 1 & 0 & 1 & 1 & 0 & 1 & 1 & 1 & 1 & 0 & 1 \\
F. polesica & 0 & 1 & 1 & 1 & 1 & 1 & 1 & 1 & 1 & 1 & 1 & 0 & 1 & 1 & 1 & 0 \\
F. ovina & 1 & 1 & 1 & 1 & 0 & 0 & 1 & 0 & 1 & 1 & 0 & 1 & 0 & 1 & 1 & 1 \\
\hline
\end{tabular}

Table 5

Coefficient of similarity (SI) values for pair-wise comparisons among the studied taxa of genus Festuca - SDS seed proteins

\begin{tabular}{|l|c|c|c|c|c|}
\hline \multirow{2}{*}{ Taxon } & \multicolumn{5}{c|}{ Coefficient of similarity (SI) values } \\
\cline { 2 - 6 } & 1 & 2 & 3 & 4 & 5 \\
\hline 1. F. vaginata & 1.00 & 0.64 & 0.64 & 0.71 & 0.31 \\
2. F. psammophila & 0.64 & 1.00 & 0.54 & 0.61 & 0.40 \\
3. F. pallens & 0.64 & 0.54 & 1.00 & 0.66 & 0.40 \\
4. F. polesica & 0.71 & 0.61 & 0.66 & 1.00 & 0.50 \\
5. F. ovina & 0.31 & 0.40 & 0.40 & 0.50 & 1.00 \\
\hline
\end{tabular}

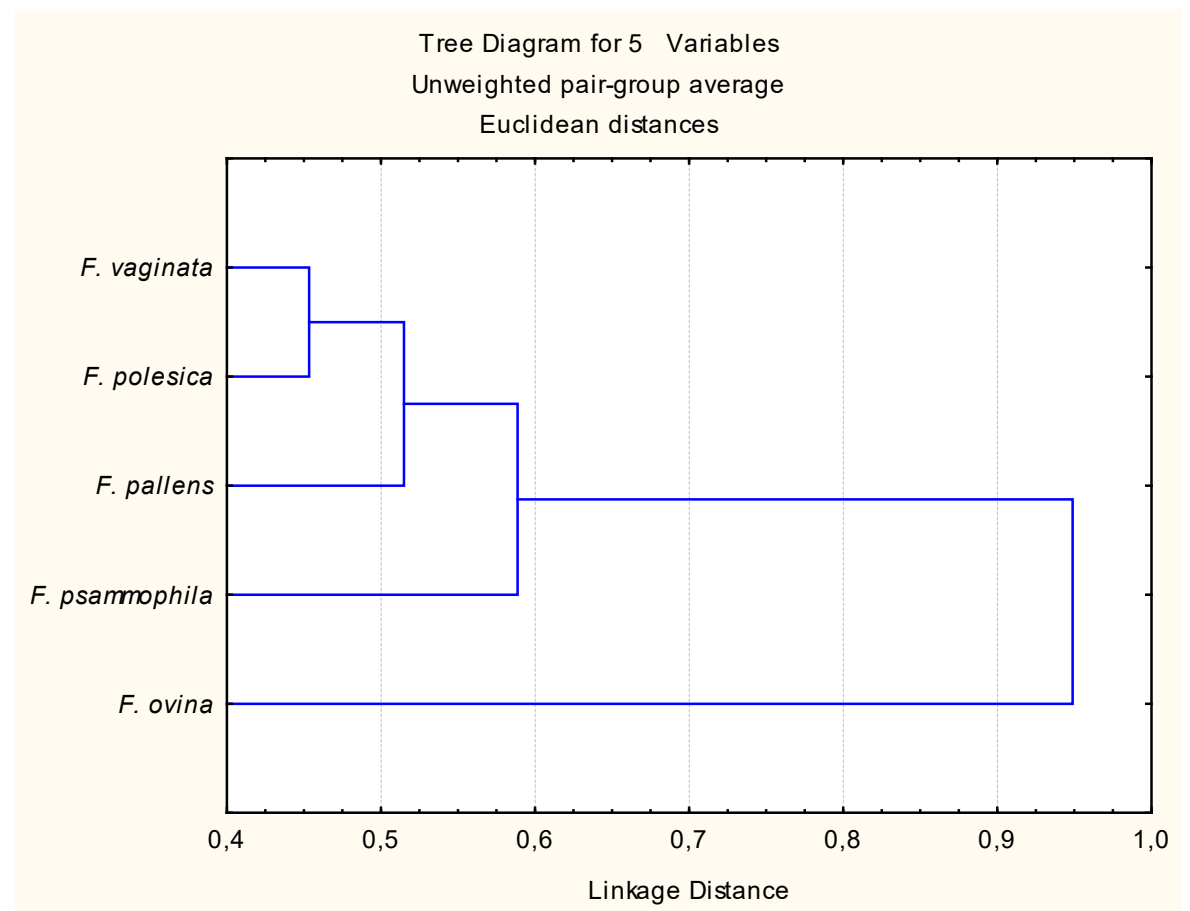

Fig. 2. Cluster analysis dendrogram for the studied Festuca species based on SDS-PAGE seed proteins

Mean values of coefficient SI for all pair-wise comparisons among the studied taxa calculated as an average of the two SI data sets (anodal, SDS-PAGE seed proteins) are presented in Table 6. 
Mean values of coefficient of similarity (SI) for pair-wise comparisons among the studied taxa of genus Festuca - anodal seed proteins and SDS-PAGE seed proteins

\begin{tabular}{|l|c|c|c|c|c|}
\hline \multirow{2}{*}{ Taxon } & \multicolumn{5}{c|}{ Coefficient of similarity (SI) values } \\
\cline { 2 - 6 } & 1 & 2 & 3 & 4 & 5 \\
\hline 1. F. vaginata & 1.00 & 0.66 & 0.57 & 0.72 & 0.30 \\
2. F. psammophilla & 0.66 & 1.00 & 0.48 & 0.56 & 0.39 \\
3. F. pallens & 0.57 & 0.48 & 1.00 & 0.52 & 0.38 \\
4. F. polesica & 0.72 & 0.56 & 0.52 & 1.00 & 0.35 \\
5. F. ovina & 0.30 & 0.39 & 0.38 & 0.35 & 1.00 \\
\hline
\end{tabular}

Graphically the data are presented in Fig. 3. The species F. vaginata, F. psammophila and $F$. polesica proved to be closely related as judged by the two data sets. The species $F$. ovina was most distantly positioned within the studied group as its SI values were the lowest for all pairwise comparisons.

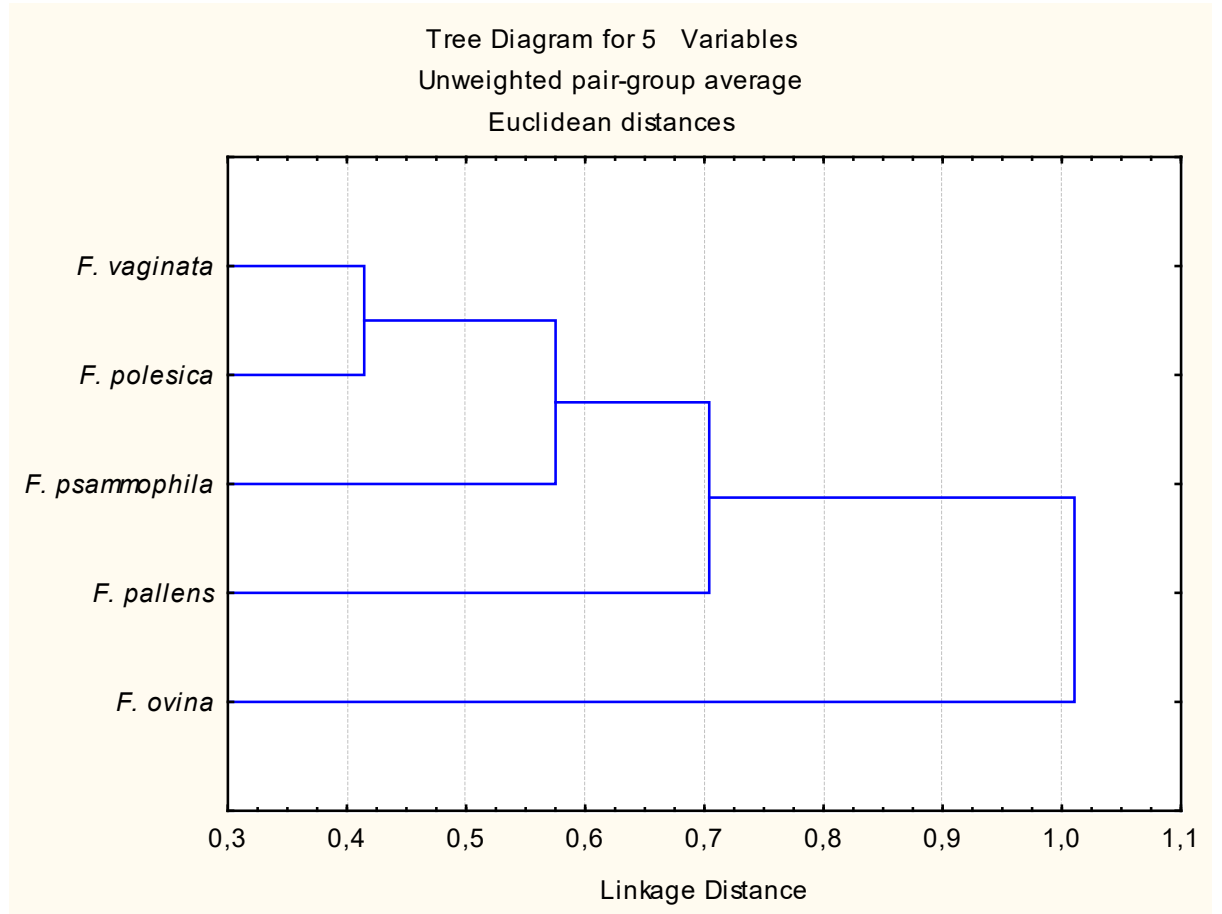

Fig. 3. Cluster analysis dendrogram based on the two SI data sets (anodal and SDS-PAGE seed proteins) for the studied Festuca species

The species $F$. ovina possessed the lowest overall value of index of group affinity $(\mathrm{GA}=1.43)$, which confirms its remote position within the studied group of the genus Festuca and supports the view to consider $F$. ovina s.str. as a separate series Ovinae among the species with sclerenchyma ring. On the contrary, the value for species $F$. vaginata $(\mathrm{GA}=2.25), F$. psammophila $(\mathrm{GA}=2.08)$ and $F$. polesica $(\mathrm{GA}=2.14)$ indicated their close affinity. The species $F$. pallens $(\mathrm{GA}=1.94)$ proved to be relatively distant from the above mentioned three species. Specific position of $F$. pallens is confirmed also by its ecological characteristics - it is the only species growing on carbonate rocks, while the rest of taxa are typical psamophytes which occur in pine 
forest sands, river terrace sands, open dunes etc. Anatomical and morphological parameters and some of biochemical markers for F. pallens and F. psammophila are very similar [2,3]. For this reason, some authors previously did not recognize $F$. psammophila as an independent species $[11,12]$. There was also a number of discussions to which of this two species the population from Ukrainian Roztocha belongs to [3]. The results we obtained using seed protein markers showed that $F$. pallens and $F$. psammophila have substantial differences between each other - they were always located in different clusters. This fact once again confirms the independent status F. psammophila, and the fact that the species indeed occurs in Ukrainian Roztocha [3]. The cluster patterns were somewhat inconsistent (Figs. 1-3) in regard to different types of proteins (PAGE, SDS-PAGE). The only exception is $F$. ovina, which always occupies a separate position. This provides evidence that there is no clear distinction among small species aggregates $(F$. beckeri agg., F. glauca agg.), that previously were reviewed in Eastern Europe [3, 12], while $F$. vaginata, F. psammophila, F. pallens, F. polesica should be considered as a separate series of closely related taxa-series Psammophilae.

\section{REFERENCES}

1. Aiken S. G., Gardiner S. E., Bassett H. C. M. et al. Implications from SDS-PAGE analyses of seed proteins in the classification of taxa of Festuca and Lolium (Poaceae) // Biochem. Syst. Ecol. 1998. 26. P. 511-533.

2. Angelov G., Bednarska I. Systematic relationships among eight taxa of genus Festuca from the Ukraine, as revealed by seed proteins electrophoresis // Phytologia Balcanica. 2016. 22 (1). P. 3-68.

3. Bednarska I. Festuca glauca agg. species in the flora of Ukraine // Visnyk L'viv Univ. Biology series. 2003. 33. P. 27-41 (in Ukrainian).

4. Carreras M., Fuentes E., Merina M. Seed proteins patterns of nine species of Cactaceae // Biochem. Syst. Ecol. 1997. 25. P. 43-49.

5. Davis B. Disc electrophoresis. I. Method and application to human serum proteins // Ann. New York Acad. Sci. 1964. 12. P. 404-427.

6. Ellison W., Alston R., Turner B. Methods for presentation of crude biochemical data for systematic purposes, with particular references to genus Bahia (Compositae) // Amer. J. Bot. 1962. 49. P. 599-604.

7. Gardiner S. E., Forde M. B., Slack C. R. Grass cultivar identification by sodium dodecylsulphate polyacrylamide gel electrophoresis // New Zeland J. Agric. Res. 1986. 29. P. 193-206.

8. Honghai Yan, Baum B. R., Pingping Zhou et al. Genetic diversity of seed storage proteins in diploid, tetraploid and hexaploid Avena species // Isr. J. Ecol. Evol. 2014. 60 (2-4). P. 47-54.

9. Pawlus M. Systematyka i rozmieszczenie gatuków grupy Festuca ovina L. w Polsce // Fragm. Flor. Geobot. 1983 (1985). 29 (2). P. 219-295.

10. Turi N., Farhatullah M., Rabani A. et al. Study of total seed storage protein in indigenous brassica species based on SDS-PAGE electrophoresis // Afr. J. Biotechnol. 2010. Vol. 9. P. 7595-7602.

11. Tveretinova V. V. Genus Festuca L. In: Prokudin Yu.N. et al. [eds.] Grasses of Ukraine. Kyiv: Naukova Dumka, 1977. P. 265-320. (In Russian).

12. Tzvelev N. Zlaki SSSR [Grasses of the U.S.S.R.]. Leningrad: Nauka, 1976. 788 p. (In Russian).

13. Yüzbaşioğlu E., Açik L., Özcan S. Seed protein diversity among lentil cultivars // Biologia Plantarum. 2008. 52 (1). P. 126-128. 
І. Беднарська, Г. Ангелов ISSN 0206-5657. Вісник Львівського університету. Серія біологічна. 2019. Випуск 81

Стаття: надійшла до редакиії 13.05.19

доопрацьована 29.07.19

прийнята до друку 25.09.19

\title{
АНАЛІЗ БІЛКІВ НАСІННЯ ВИДІВ СЕРІї FЕSТUСА PSAMMOPHILAE M. PAWLUS TA OVINAE M. PAWLUS (POACEAE)
}

\author{
І. Беднарська ${ }^{1}$, Г. Ангелов ${ }^{2 *}$ \\ 'Iнститут екології Карпат НАН України \\ вул. Козельницька, 4, Львів 79026, Украӥна \\ e-mail:ibednarska@ukr.net \\ ${ }^{2}$ Інститут Біорізноманіття та \\ Вивчення Екосистем Болгарської Академї Наук \\ вул. акад. Г. Бончева, 23, Софія, Болгарія \\ *e-mail:jorkata_1953@mail.bg
}

Для ідентифікації вузьколистих видів роду Festuca традиційно використовують ознаки анатомічної будови листків. Загалом, можна виділити три основні групи видів: ті, що мають анатомію за типом F. rubra (численні тонкі тяжі склеренхіми), за типом $F$. valesica (є три основних грубих і можливі додаткові тяжі) та за типом F. ovina (наявне кільце склеренхіми). У межах останньої групи, за різними авторами, виділяють низку дрібних видових агрегатів, трактування обсягів яких (спорідненості) у різних авторів $є$ досить відмінним. Метою роботи було провести аналіз філогенетичної спорідненості низки видів із кільцем склеренхіми за альтернативними до класичних морфологічних ознак біохімічними маркерами, зокрема, за протеїнами білків. За допомогою електрофорезу в поліакриламідному гелі (PAGE) та додецилсульфаті натрію (SDS-PAGE) було досліджено мінливість білків насіння п'яти видів костриць флори України та Болгарії: Festuca vaginata, F. psammophila, F. pallens, F. polesica та F. ovina. Результати показали, що F. vaginata, F. psammophila та F. polesica виявилися досить тісно пов'язаними між собою, тоді як $F$. pallens є порівняно віддаленою від них. Специфічне положення $F$. pallens підтверджується іiі екологічними особливостями - це єдиний вид серії, що росте на карбонатних породах, у той час як всі інші таксони є типовими псамофітами. Результати показали також чіткі відмінності між українськими популяціями $F$. pallens i $F$. psammophila. Цей факт є особливо важливим 3 огляду на нещодавні сумніви стосовно визнання останньої самостійним видом. Отримані дані підтвердили гіпотезу виростання $F$. psammophila на українському Розточчі та доцільність розглядати ії як окремий вид. Найвіддаленішою від усіх виявилася F. ovina, яка в межах досліджуваної групи має найменші морфологічні параметри та найтонші листки. Отримані результати підтверджують іiї приналежність до окремої серії Ovinae серед видів із кільцем склеренхіми. Дендрограми кластерного аналізу були трохи відмінні за результатами щодо різних типів білків (PAGE, SDS-PAGE). Це свідчить про відсутність чіткого розмежування малими видовими агрегатами. Звідси можна зробити висновок, що всі інші досліджувані види (F. vaginata, F. psammophila, F. pallens, F. polesica) слід розглядати як окрему серію близькоспоріднених таксонів серію Psammophilae.

Ключові слова: електрофорез, Festuca, насіннєві білки, систематика, взаємовідносини 